\title{
Manajemen Risiko di Era Covid-19 Terhadap Ekonomi di Indonesia
}

\author{
Uly Mabruroh Halida ${ }^{1)}$ \\ 1) Institut Agama Islam Negeri Madura, Pamekasan, Indonesia \\ Corresponding author: ulyhalida@iainmadura.ac.id
}

\begin{abstract}
:
The period of the Covid-19 pandemic was able to change almost all patterns of community activity in the world. Anything that invites a large crowd or community involvement should be avoided. So that this will cause many risk impacts in all sectors of life including the economic sector in it. Risk is a consequence that is not good and can hinder a certain goal. So good risk management is needed in a situation like this in order to be able to deal with all the risks that arise due to covid-19. This study aims to determine Risk Management in the Covid19 era in the economic field. This type of research is a type of library research, data analysis, data reduction, data display. The conclusions of the results of this study indicate that Risk Management in the Covid-19 era in the current economy with various impacts on the economy due to the Covid-19 pandemic, namely difficulties in finding employment, difficulty meeting daily needs, even having no income. in fulfilling the necessities of life and there are many more risks that occur from other economic sectors. As for what the government has done to minimize this risk, namely by issuing several monetary and fiscal policies in the hope of being able to restore the state of the Indonesian economy.
\end{abstract}

Keywords: Risk management, Covid-19, Economics

\begin{abstract}
Abstrak:
Masa pandemic covid-19 mampu mengubah hampir semua pola aktivitas masyarakat di dunia. Segala sesuatu yang mengundang kerumunan atau keterlibatan masyarakat banyak harus di hindari. Sehingga hal tersebut akan menimbulkan banyak dampak risiko dalam segala sektor kehidupan termasuk sektor ekonomi yang ada di dalamnya. Risiko merupakan suatu akibat yang tidak baik dan mampu menghambat suatu tujuan tertentu. Maka adanya manajemen risiko yang baik sangat dibutuhkan dalam situasi seperti ini agar mampu menanggulangi segala risiko yang timbul akibat covid-19. Penelitian ini bertujuan untuk mengetahui Risk Management di era Covid-19 dalam bidang ekonomi. Jenis penelitian ini merupakan jenis penelitian kepustakaan analisis data, reduksi data, display data. Adapun kesimpulan hasil penelitian ini menunjukkan bahwa Risk Management di era Covid-19 dalam bidang ekonomi saat ini dengan berbagai dampak yang terjadi terhadap perekonomian karena pandemic Covid-19 yaitu kesulitan dalam mencari lapangan pekerjaan, kesulitan untuk memenuhi kebutuhan sehari-hari, bahkan tidak mempunyai penghasilan dalam memenuhi kebutuhan hidup dan masih banyak lagi risiko yang terjadi dari sektor ekonomi lainnya. Adapun yang dilakukan pemerintah untuk meminimalisir risiko tersebut yaitu dengan cara mengeluarkan beberapa kebijakan moneter dan fiscal dengan harapan mampu memulihkan keadaan ekonomi Negara Indonesia.
\end{abstract}

Kata Kunci: Manajemen risiko, Covid-19, Ekonomi 


\section{PENDAHULUAN}

Pada tanggal 2 Maret 2020 lalu, pemerintah Indonesia telah menginformasikan bahwa terdapat dua kasus Virus Corona atau yang sering dikenal dengan Covid-19, seperti yang telah kita ketahui bersama bahwa penyebaran virus corona tersebut terus meningkat menjadi sebanyak 1,53 juta kasus infeksi per Minggu, 4 April 2021 yang di dalamnya termasuk kasus 41.242 jiwa meninggal dunia dan 1,37 juta jiwa yang dinyatakan sembuh. ${ }^{1}$ Dalam kondisi seperti saat ini, virus corona bukanlah suatu wabah yang bisa kita abaikan begitu saja. Namun jika kita lihat dari gejala-gejala yang ada, kebanyakan orang akan mengira bahwa hal tersebut hanyalah sebatas influenza biasa, akan tetapi hal itu jika di analisis dalam bidang kedokteran virus corona tersebut cukup berbahaya dan bahkan mematikan. Di tahun 2020, penularan virus corona ini cukup signifikan karena penyebarannya sudah mendunia dan bahkan seluruh Negara di dunia merasakan dampak dari virus ini termasuk Indonesia. ${ }^{2}$ Suatu analisis mencoba untuk mengukur laju penularan berdasarkan masa inkubasi, gejala dan durasi antara gejala dengan pasien yang diisolasi. Analisis tersebut mendapatkan hasil penularan dari 1 pasien ke sekitar kurang lebih 3 orang disekelilingnya, akan tetapi kemungkinan penularan di masa inkubasi ini akan menyebabkan masa kontak pasien ke orang sekelilingnya lebih lama lagi sehingga risiko untuk jumlah kontak yang tertular dari 1 pasien tersebut kemungkinan dapat menjadi lebih besar. ${ }^{3}$ Untuk mengantisipasi dan mengurangi jumlah penderita virus corona di Indonesia sudah dilakukan di seluruh tempat, diantaranya dengan cara memberikan kebijakan untuk membatasi aktifitas keluar rumah, bekerja dari rumah (work from home), kegiatan belajar mengajar di sekolah dirumahkan, bahkan untuk kegiatan beribadahpun dirumahkan. Hal tersebut tentunya sudah menjadi kebijakan pemerintah dengan berdasarkan pertimbangan yang sudah dianalisa dengan sangat maksimal tentunya.

Indonesia sendiri telah membuat aturan kebijakan pembatasan untuk bepergian baik itu ke negara-negara yang masuk zona merah maupun dari negara-negara yang masuk dalam zona merah penularan selama pandemic covid-19 dengan tujuan untuk memutus mata rantai penularan covid-19, hal ini mengikuti kebijakan yang telah lebih dulu dilaksanakan oleh beberapa negara. Kebijakan pembatasan ini telah memberikan dampak terhadap jadwal penerbangan, karena beberapa maskapai telah melakukan pembatalan terbang dan juga sebagian maskapai lainnya terpaksa tetap melaksanakan pernerbangan meskipun sebagian besar tempat atau porsi penumpang pesawatnya tidak terisi demi menjaga dan memenuhi hak pelanggan. Akan tetapi sebagian besar pelanggan juga melakukan cancel teradap tiket penerbangan yang telah di pesan dikarenakan semakin mewabahnya sebaran covid-19. Situasi yang demikian tentunya memaksa pemerintah untuk memberikan suatu kebijakan dengan memberikan potongan harga tiket untuk para penumpang misalkan dengan tujuan kota-kota terntu seperti Malang, Batam, Lombok, Yogyakarta dan Denpasar.

Kegiatan ekspor terbesar di dunia dipegang oleh China. ${ }^{4}$ Negara yang sering melakukan impor dari kegiatan ekspor yang dilakukan oleh China salah satunya adalah Indonesia. Selain itu, China juga adalah salah satu mitra dagang terbesar yang dimiliki oleh Indonesia. Munculnya Covid-19 yang menjangkit China membawa kegiatan perdaganga China kearah yang negative sehingga berdampak pada alur dan system perdagangan dunia yang lain. Hal ini tentunya juga berdampak terhadap keadaan Indonesia. Menurunnya kelapa sawit dan batu bara serta impor bahan mentah lainnya dari China akan menyerang kegiatan ekspor

\footnotetext{
1 "JHU CSSE COVID-19 Data," n.d.

${ }^{2}$ Risma Ikawaty, “Corona Virus,” 2020, https:/www.ubaya.ac.id/2020/ content/articles_detail/288/ CORONAVIRUS-.

${ }^{3}$ Diah Handayani, "Penyakit Virus Corona 2019," Jurnal Respirologi Indonesia 40 (2020): 122.

${ }^{4}$ Yang L and Ren Y, "Moral Obligation, Public Leadership, and Collective Action for Epidemic Prevention and Control: Evidence from the Corona Virus Disease 2019 (COVID-19) Emergency," International Journal of Environmental Research and Public Health 17 (2020): 1-16.
} 
di Indonesia sehingga akan menimbulkan turunnya harga barang tambang dan komoditas lainnya. ${ }^{5}$

Dampak dari Covid-19 ini tidak hanya menggangu sektor ekspor dan impor di Indonesia, melainkan juga akan menyerang pada sektor perdagangan yaitu dari penerimaan pajak yang juga akan mengalami penurunan. Hal ini tentunya akan berdampak sangat serius karena dalam hal penerimaan pajak sektor perdagangan disini sangat memiliki kontribusi yang cukup besar dalam mendongkrak penerimaan negara tepatnya yaitu berada pada urutan kedua terbesar. ${ }^{6}$

Badan Pusat Statistik (BPS) merilis data yang terkait dengan ekspor migas dan non migas yang menyebutkan terjadinya penurunan ekspor migas dan non-migas yang tentu dampaknya ditimbulkan oleh pandemi saat ini, jadi hal ini tentunya tidak heran karena memang China merupakan importir minyak mentah terbesar di dunia. Dalam hal ini, pandemi covid-19 juga menyebabkan turunnya produksi yang telah dihasilkan oleh China, padahal tumpuan barang dunia dan juga produksi sentral barang dunia terpusat di China. Apabila nantinya terjadi koreksi yang negative atas produksi di China maka dunia akan mengalami gangguan supply chain yang pada akhirnya juga dapat menurunkan proses produksi dunia yang bahan bakunya di impor dari China. Negara Indonesia sendiri tentunya sangat membutuhkan bahan baku dari China untuk melakukan proses produksi khusunya bahan baku elektronik, tekstil, plastik, funitur dan komputer.

Penyebaran virus corona juga berdampak pada sektor investasi, perdagangan, usaha mikro, kecil dan menengah (UMKM) karena para wisatawan yang biasanya datang ke suatu destinasi akan membeli oleh-oleh. Jika jumlah wisatawan yang berkunjung berkurang, maka tentunya omset yang diperoleh UMKM juga akan menurun. Berdasarkan data Bank Indonesia, pada tahun 2016 sektor UMKM mendominasi unit bisnis di Indonesia dan jenis usaha mikro banyak menyerap tenaga kerja. Di lain sisi, virus corona ini tidak hanya memberi dampak negative, namun juga dapat memberikan dampak positif bagi perekonomian Indonesia. Salah satunya adalah terbukanya peluang pasar ekspor baru selain China. Selain itu peluang untuk memperkuat ekonomi dalam negeri dapat terlaksana karena pemerintah akan lebih memproiritaskan dan memperkuat daya beli dalam negeri daripada menarik keuntungan dari luar negeri. Kondisi ini juga tentunya dapat dimanfaatkan sebagai koreksi agar investasi bisa stabil meskipun perekonomian global sedang terguncang.

Ekonomi merupakan salah satu faktor penting dalam kehidupan manusia. Dapat dipastiakn dalam keseharian kehidupan manusia selalu bersinggungan dengan kebutuhan ekonomi. Keberadaan ekonomi dapat memberikan kesempatan bagi manusia untuk memenuhi kebutuhan hidupnya seperti makanan, minuman, berpakaian, tempat tinggal, dan lain sebagainya. Pentingnya ekonomi dalam kehidupan manusia tersebut menuntut Negara untuk mengatur kebijakan tentang perekonomian dan menjamin perekonomian warga negara khusunya di Indonesia yang memproklamirkan diri sebagai negara kesejahteraan (welfare staat). Dalam konsep negara kesejahteraan adalah negara berhak untuk ikut andil dalam segala aspek kehidupan warga negaranya termasuk dalam bidang ekonomi. Selain itu pertumbuhan ekonomi juga merupakan faktor yang mendukung pembangunan nasional dalam suatu negara, karena pertumbuhan ekonomi yang baik akan dapat meningkatkan pembangunan nasional.

Melihat dampak ekonomi akibat mewabahnya virus Covid 19 ini, maka pemerintah perlu mengambil langkah yang paling efektif untuk menjaga agar perekonomian Indonesia bisa tetap stabil sehingga hal ini bisa menjadi peluang sekaligus tantangan bagi perilaku

\footnotetext{
${ }^{5}$ Iswahyudi H, "Back to Oil: Indonesia Economic Growth After Asian Financial Crisis," Economic Journal of Emerging Markets 8 (2016): 25-44.

${ }^{6}$ Sugarda P and Rifky W, "Strengthening Indonesia's Economic Resilience through Regulatory Reforms in Banking, Investment and Competition Law," Journal of Economic \& Management Perspectives 11 (2017): 1093-1103.
} 
ekonomi untuk mengambil peran dalam rangka membantu pemerintah untuk menstabilkan ekonomi Indonesia. Konstitusi di Indonesia telah memberikan batasan terkait dengan perekonomian nasional sebagaimana yang tercantum dalam Pasal 33 ayat (4) NKRI 1945 yang menyebutkan bahwa, "Perekonomian nasional diselenggarakan berdasar atas demokrasi ekonomi dengan prinsip kebersamaan, efisiensi keadlilan, berkelanjutan, berwawasan lingkungan, kemandirian, serta dengan menjaga keseimbangan kemajuan dan kesatuan ekonomi nasional." Dalam pasal tersebut menegaskan bahwa perekonomian dalam hal ini keberadaan industri harus berwawasan lingkungan. Dalam hal ini insdustri dituntut untuk mampu mengolah limbah hasil usaha industri tersebut supaya tidak mencemari lingkungan.

Berdasarkan uraian di atas, maka tujuan dari penulisan artikel ini adalah untuk mendeskripsikan bagaimana risiko manajemen di era Covid 19 dalam bidang ekonomi. Apabila melihat dari situasi yang sekarang dialami oleh masyarakat Indonesia karena adanya Covid 19 sehingga membuat perekonomian Indonesia memberikan begitu banyak pengaruh dalam berbagai sektor terutama sektor ekonomi. Salah satunya terhadap manajemen risiko dalam ekonomi di Indonesia.

\section{METODE PENELITIAN}

Penelitian ini bertujuan untuk mengetahui risiko manajemen di Era Covid 19 dalam bidang ekonomi di Indonesia. Penelitian ini termasuk dalam penelitian pustaka dengan pendekatan analysis content, penelitian pustaka didefinisikan sebagai studi yang mempelajari berbagai buku referensi serta hasil penelitian sebelumnya yang sejenis yang berguna untuk mendapatkan landasan teori tentang masalah yang akan diteliti. ${ }^{7}$ Jadi dalam penelitian ini tidak perlu terjun langsung ke lapangan akan tetapi mengambil berbagai referensi yang mendukung dalam penelitian ini. Penelitian ini termasuk dalam jenis penelitian kualitatif. Tekhnik pengumpulan datanya yaitu dengan menyimak dan mencatat informasi penting dalam melakukan analisis data penting dalam melakukan analisis data dengan cara reduksi data, display data dan gambaran kesimpulan sehingga mendapatkan suatu gambaran mengenai kesimpulan studi literatur guna untuk dikembangkan dalam penelitian ini, sedangkan untuk validasi datanya menggunakan triangulasi sumber data.

\section{HASIL DAN PEMBAHASAN}

\section{A. Manajemen Risiko}

Setiap orang atau pun perusahaan hakikatnya selalu ingin terhindar dan meminimalisir adanya suatu resiko yang hendak terjadi. Hal itu dikarenakan naluri dari seseorang yang ingin selalu berada dalam situasi yang nyaman, aman dan tidak mengalami kerugian dari sisi apapun. Namun kehidupan penuh dengan pilihan, dan setiap pilihan pasti memiliki sisi ketidakpastian yang mengandung resiko. Risiko merupakan fenomena yang tidak bisa di hindari baik itu risiko kecil ataupun besar. Sehingga dapat diartikan bahwa risiko merupakan bagian dari kehidupan sehari-hari manusia itu sendiri. Artinya kehidupan manusia dengan kemungkinan terjadinya risiko itu saling berdampingan. Risiko sering diartikan sebagai ketidakpastian (uncertainty). ${ }^{8}$ Kerena keberadaannya yang memang belum pasti terjadi. Risiko adalah kejadian-kejadian yang potensi untuk terjadi mungkin dapat menimbulkan kerugian pada suatu perusahaan. ${ }^{9}$ Risiko juga diartikan sebagai suatu kejadian atau peristiwa yang apabila terjadi dapat menghambat pencapaian tujuan atau sasaran divisi

\footnotetext{
${ }^{7}$ Milya Sari and Asmendri, "Penelitian Kepustakaan (Library Research) Dalam Penelitian Pendidikan IPA," NATURAL SCIENCE: Jurnal Penelitian Bidang IPA Dan Pendidikan IPA 6 (2020): 43.

${ }^{8}$ Hinsa Siahaan, Manajemen Risiko Konsep, Kasus Dan Implementasi (Jakarta: PT. Elek Media Komputindo, 2007), 1.

${ }^{9}$ Reni Maralis and Aris Triyono, Manajemen Risiko (Yogyakarta: CV. Budi Utama, 2019), 5.
} 
atau perusahaan.10 Dalam suatu risiko mencakup dua aspek penting, yaitu aspek probabilitas/kemungkinan dan aspek kerugian/dampak. ${ }^{11}$ Dimana aspek probabilitas/kemungkinan tersebut menandakan bahwa risiko masih bersifat ambigu yaitu bisa benar terjadi atau bisa segera diatasi sebelum risiko tersebut benar terjadi. Sedangkan aspek kerugian/dampak yaitu apabila suatu risiko tidak bisa diantisipasi secara dini maka akan menyebabkan kerugian. Dari kerugian tersebut akan merembet kepada timbulnya dampak-dampak lain yang bisa menghambat tujuan tertentu.

Beberapa hal yang menjadi penyebab dari timbulnya risiko yaitu adanya penyimpangan, suatu ketidakpastian dimasa mendatang dan terjadinya sesuatu yang tidak direncanakan atau tidak di harapkan. Kondisi ketidakpastian tersebut dapat muncul karena beberapa sebab yaitu diantaranya:

1. Tenggang waktu antara perencanaan suatu kegiatan sampai kegiatan itu berakhir, di mana tenggang waktu tersebut harus direncanakan secara baik dan sistematik. Kemudian proses pelaksanaannya harus sesuai dengan tenggang waktu yang telah direncanakan di awal. Karena semakin panjang tenggang waktunya akan makin besar ketidakpastiannya.

2. Keterbatasan informasi yang tersedia yang diperlukan untuk penyusunan rencana. Informasi menjadi poin penting bagi pengambilan keputusan. Apabila informasi yang diperoleh tidak menyeluruh atau terbatas, maka besar kemungkinan akan menghasilkan perencanaan yang salah sehingga menimbulkan adanya risiko.

3. Keterbatasan pengetahuan/kemampuan pengambilan keputusan dari perencana. Sama halnya dengan informasi, pengetahuan/kemampuan juga menjadi poin penting dalam pengambilan keputusan untuk menyusun suatu perencanaan yang baik. ${ }^{12}$

Sedangkan manajemen risiko yaitu proses sistematik untuk mengelola timbulnya risiko. Manajemen risiko adalah penerapan fungsi-fungsi manajemen dalam penanggulangan risiko, terutama risiko yang dihadapi oleh organisasi/perusahaan, keluarga dan masyarakat. ${ }^{13}$ Manajemen risiko juga diartikan sebagai suatu strategi yang digunakan untuk mengevaluasi dan mengelola semua risiko dalam perusahaan. ${ }^{14}$ Terdapat empat langkah dalam proses manajemen risiko yaitu meliputi: identify risk, evaluate risk, select ris management techniques, dan implement and review techniques. ${ }^{15}$ Informasi yang diperoleh dari manajemen risiko sangat bermanfaat bagi pihak-pihak yang terkait seperti investor, pemasok, kreditur, pemegang saham dan pihak-pihak lainnya yang memiliki kepertingan. ${ }^{16}$ Cakupan dari kegiatan manajemen risiko yaitu perencanaan, pengorganisasian, kepemimpinan, pengkoordinasian dan pengawasan terhadap program penanggulangan risiko tersebut. Adapun manajemen risiko yang baik yaitu apabila dapat meminimalisir bentukbentuk kerugian yang hendak di hadapi oleh seseorang atau badan.

Manajemen dapat dikatakan bagus yaitu apabila suatu manajemen dapat mengelola risiko untuk di hindari atau berada di titik terminim terjadinya risiko, karena pada kenyataannya tidak semua risiko bisa untuk dihindari sehingga hal tersebut tergantung dengan bagaimana cara dan kemampuan untuk mengelola risiko itu sendiri. Terkadang banyak orang yang mampu memandang suatu risiko dengan sisi yang berbeda. Yaitu dengan cara memanfaatkan adanya risiko tersebut sebagai peluang baginya untuk melakukan hal lain yang lebih menguntungkan. Jadi peran dari manajemen risiko ini penting untuk mengubah

\footnotetext{
${ }^{10}$ Hery, Manajemen Risiko Bisnis (Jakarta: PT. Grasindo, 2015), 2.

${ }^{11}$ Opan Arifudin, Udin Wahrudin, and Fenny Damayanti Rusmana, Manajemen Risiko (Bandung: Widina Bhakti Persada, 2020), 1.

${ }_{12}$ Maralis and Triyono, Manajemen Risiko, 5.

${ }^{13}$ Maralis and Triyono, 8.

${ }^{14}$ Indra Siswanti et al., Manajemen Risiko Perusahaan (Medan: Yayasan Kita Menulis, 2020), 13.

${ }^{15}$ Siahaan, Manajemen Risiko Konsep, Kasus Dan Implementasi, 19.

${ }^{16}$ Arifudin, Wahrudin, and Rusmana, Manajemen Risiko, 17.
} 
suatu risiko menjadi peluang yang bermanfaat dan menguntungkan. Kemanfaatan manajemen risiko berbicara terkait dengan kuangan akan menjadi suatu arah dalam mengatur langkah strategis untuk meningkatkan tingkat keamanan perekonomian, melalui suatu prosedur penerapan yang dikomunikasikan secara berkesinambungan dan berkelanjutan dengan kebijakan manajemen, pemilihan alternatif terbaik dengan analisis secara komprehensif, kuantifikasi keuangan untuk mengurangi sejumlah dampak yang mengancam sisi perekonomian. ${ }^{17}$

Secara teoritik bentuk dari manajemen resiko yaitu ada dua yang terdiri dari; pertama Pure Risk (Risiko Murni), yaitu suatu risiko yang bilamana terjadi akan memberikan kerugian dan apabila tidak terjadi maka tidak menimbulkan kerugian namun juga tidak menimbulkan keuntungan. Dampak dari adanya risiko ini yaitu ada dua macam: antara rugi atau break event. Seperti contohnya kejadian yang tidak terduga yaitu pencurian, kecelakaan atau kebakaran. Kemudian yang kedua yaitu speculative risk (risiko Sekulatif), yaitu risiko yang berkaitan dengan terjadinya tiga kemungkinan, yaitu peluang mengalami kerugian, break even atau memperoleh keuntungan. Contohnya yaitu bisa ditemu dalam kegiatan investasi. ${ }^{18}$

\section{B. Pandemi COVID-19 di Indonesia}

Saat ini hampir diseluruh dunia telah merasakan dampak dari adanya pandemi Covid19. Para peneliti berpendapat bahwa akan membutuh waktu lebih dari satu dekade untuk memulihkan kembali atau mengembalikan tatanan kehidupan seperti sedia kala bagi seluruh dunia. Di Indonesia, pada triwulan I tahun 2020 tepatnya tanggal 2 Maret 2020, Presiden Jokowi mengkorfirmasi bahwa ada dua orang warga Indonesia yang telah terjangkit virus covid-19 yang sangat menular dan mematikan ini. Wabah ini dalam sekejap berkembang di seluruh Indonesia, hingga pada minggu terakhir Maret 2021 kasus positif covid-19 bertambah dari 6.107 menjadi 1.482.559 kasus. Pasien sembuh juga bertambah dari 4.656 menjadi 1.313.199 orang. Pasien meninggal bertambah dari 98 menjadi 40.081 orang. Penyebaran virus yang bermula dari kota Wuhan di Cina ini sudah ditetapkan sebagai pandemic oleh Badan Kesehatan Dunia WHO karena virus yang sangat mudah menular ini terdeteksi secara global.

World Health Organization (WHO) menjelaskna bahwa Coronaviruses (Cov) merupakan virus yang menginfeksi system pernapasan. Infeksi virus ini disebut Covid-19. Virus corona ini menyebabkan penyakit flu biasa sampai penyakit yang lebih parah seperti Sindrom Pernapasan Timur Tengah (MERS-CoV) dan Sindrom Pernapasan Akut Parah (SARS$\mathrm{CoV}$ ). Virus ini sangat cepat penularannya dan telah menyebar ke beberapa negara, termasuk Indonesia. Seseorang dapat tertular virus covid-19 ini melalui berbagai cara, yaitu:

1. Memegang mulut atau hidung tanpa mencuci tangan terlebih dahulu setelah menyentuh benda yang terkena bekas air liur penderita covid-19.

2. Kontak jarak dekat dengan penderita covid-19, misalnya berjabat atau bersentuhan.

3. Tidak sengaja menghirup percikan ludah dari bersin atau batuk penderita covid-19.

Covid-19 ini tentu saja bukan sekedar virus yang hanya mengancam kesehatan, akan tetapi dampak secara tidak langsung yang utama adalah gangguan ekonomi negara-negara di seluruh dunia termasuk Indonesia. Bahkan pertumbuhan ekonomi dunia diprediksi dapat merosot hingga $0,3 \%$ atau bahkan sampai 0,4\%. Jika krisis keuangan 2008 mengakibatkan penurunan Produk Domestik Bruto (PDB) global sebesar 0,1\% pada 2009, maka resesi ekonomi akibat pandemi covid-19 yang disebut sebagai Great Lockdown dapat menurunkan

\footnotetext{
${ }^{17}$ Muhlis, "Strategi Manajemen Risiko Pemanfaatan Teknologi Pada Lembaga Keuangan Syariah Era Millennial Dan Covid 19," Ar-Ribh: Jurnal Ekonomi Islam 3 (2020): 158.

${ }^{18}$ Aris Susetyo and Anton Prasetyo, "Pelatihan Manajemen Resiko Bagi Usaha Mikro Kecil Dan Menengah Di Era Pandemi Covid-19,” Journal of Community Service and Empowerment 1 (2020): 85.
} 
PDB global sebesar 3\%. Perlambatan ekonomi global memaksa pemerintah di seluruh dunia melakukan upaya untuk menekan dampaknya.

Indonesia merupakan Negara yang memiliki penduduk terpadat keempat di dunia, sehingga jika dibandingkan dengan negara-negara lainnya maka diperkirakan bahwa Indonesia akan menderita lebih lama. Ketika kita melihat penyebaran covid-19 terbesar berada di pulau jawa, maka disini bisa kita lihat bahwa kurangnya kesadaran masyarakat dalam menyikapi terjadinya penyebaran virus mematikan ini sehingga banyak sekali masyarakat yang masih enggan untuk menggunakan masker, dan juga banyaknya masyarakat yang masih sering berkumpul di keramaian yang tentunya tanpa memikirkan social distancing. Tentunya adanya kesadaran bersama sangat diperlukan demi mendukung pemerintah dalam mencegang atau memutus penyebaran virus mematikan ini. Tentunya disini sangat diperlukan kerjasama anatar masyarakat dan pemerintah demi bersama-sama melawan agar virus ini segera berakhir supaya kehidupan kita dapat berjalan normal kembali.

Langkah pertama untuk mengurangi dan mencegah penularan virus mematikan ini adalah memberlakukan karantina, baik yang menyeluruh maupun karantina local (Lockdown). Masyarakat sangat dianjurkan untuk menetap di rumah selama 14 hari dan menjaga jarak minimal 1,5 meter dari sekelilingnya (Physical distancing). Dengan adanya Covid-19 ini banyak sekali merubah pola hidup masyarakat pada umumnya. Segala aktivitas yang melibatkan kerumunan banyak orang mulai dibatasi seperti perusahaan dan kantor yang mulai menerapkan WFH (Work From Home). Para siswa dan mahasiswa mulai melaksanakan proses pembelajaran jarak jauh (daring) dengan memanfaatkan teknologi yang ada. Mall dan tempat wisata lainnya mulai ditutup. Bahkan pasar tradisional juga mendapat perlakuan pemantauan yang ketat oleh pihak yang bertugas. Tentunya hal tersebut menjadi penyebab utama melambatnya perekonomian karena masyarakat dipaksa untuk tidak berkegiatan diluar rumah. Apalagi bagi mereka yang bergantung kepada pemanfaatan pasar secara langsung. Salah satu sektor yang menjadi bagian dari penggerak roda ekonomi Negara yang membutuhkan keterlibatan seseorang secara langsung di dalamnya yaitu sektor pariwisata. Dalam suasana pandemic ini, sektor pariwisata mengalami keterpurukan angka yang sangat memprihatinkan. Berikut ini merupakan data wisata di Indonesia selama tahun 2020:

Gambar 1.

Kunjungan Wisata Negara Indonesia Selama Tahun 2020

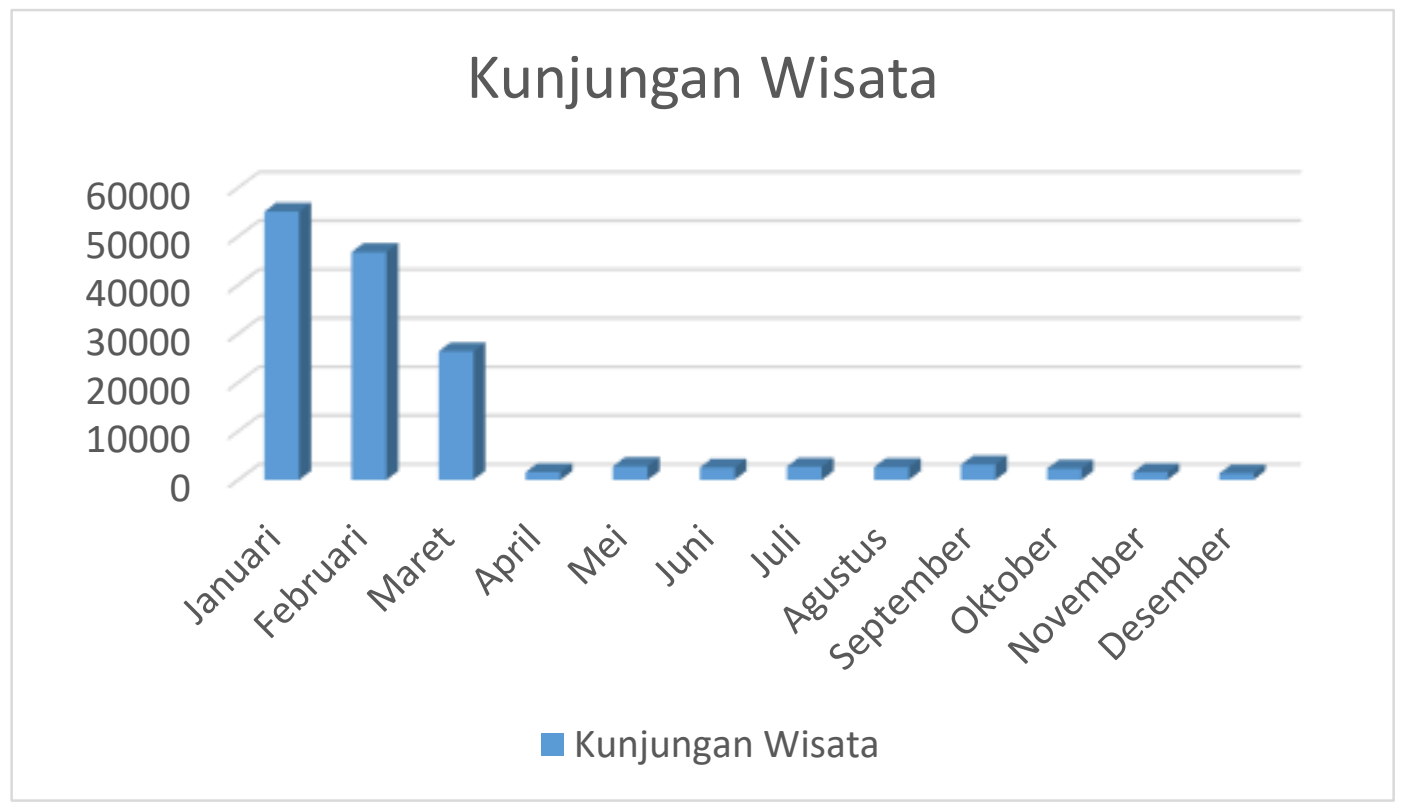




\section{Sumber : Badan Pusat Statistik}

Dari diagram batang tersebut dapat dilihat bahwa jumlah wisata di Negara Indonesia sebelum dikabarkan adanya 2 kasus positif covid-19 yaitu masih normal berada di angka 55.075 wisata. Namun bulan berikutnya dan seterusnya memang mengalami angka penurunan yang semakin drastis karena pada tahun 2020 merupakan masa pandemi di seluruh dunia sehingga banyak Negara-negara lain yang melaksanakan lackdown untuk menghindari atau meminimalisir tingkat penyebaran covid-19 yang saangat cepat. Hingga pada bulan Maret 2020 adalah menjadi awal adanya kasus covid-19 di Indonesia dan mengharuskan Indonesia membatasi segala aktivitas dalam Negara maupun keluar negera dengan diterapkannya PSBB (Pembatasan Sosial Berskala Besar). Dampak penerapan tersebut sangat berpengaruh terhadap jumlah kunjungan wisata dimana pada bulan Maret jumlah kunjungan wisata masih sebesar 26.399. Kemudian pada bulan April jumlah kunjungan wisata sudah berada pada angka 1.588. Bulan-bulan selanjutnya data kunjungan wisata hanya berkisar di angka 1.000 sampai 3.000 saja. Sehingga dari potretan data kunjungan wisata saja sudah dapat di prediksi bagaimana keadaan ekonomi Negara Indonesia pada masa pandemi covid-19 ini.

\section{Manajemen Risiko Ekonomi di Masa COVID-19}

Salah satu faktor penting lainnya dalam kehidupan manusia adalah faktor ekonomi. Dapat dipastikan kehidupan manusia tidak pernah terlepas dari kegiatan ekonomi. Keberadaan ekonomi dapat memberikan kesempatan bagi manusia untuk memenuhi kebutuhannya. Namun, dengan adanya pandemi covid-19 ini banyak sekali pihak ataupun hal yang dirugikan. Yang sangat terasa dampaknya pada kegiatan ekonomi dimana didalamnya banyak kegiatan ekonomi yang terganggu dan berakibat ke semua badan atau lembaga perekonomian. ${ }^{19}$ Adanya covid-19 sangat berpengaruh terhadap Negara Indonesia khususnya pada aspek ekonomi. Banyak sektor yang mengalami hambatan dalam kelangsungan aktivitasnya. Sektor utama yang paling terdampak dalam bidang ekonomi yaitu sektor pariwisata. Dari sektor pariwisata tersebut berimbas kepada sektor-sektor lain yang masih memiliki keterkaitan erat dengan sektor pariwisata itu sendiri yaitu seperti perhotelan, transportasi, restoran, retail dan lain sebagainya. Situasi pandemi covid-19 ini juga menyebabkan terjadinya penurunan signifikan aktifitas supply dan demand barang dan jasa. Di sektor manufaktur juga mengalami kendala akibat supply bahan baku yang berasal dari Cina terhambat. Hal yang menjadi penyebab utama pada kejadian ini yaitu adanya segala macam peraturan yang mengharuskan banyak masyarakat untuk mengkarantina dirinya sendiri. Sehingga dari fenomena tersebut mengakibatkan penurunan pendapatan, bahkan terjadinya PHK massal. Adanya dampak ekonomi dari masa pandemi covid-19 ini juga sangat dirasakan oleh perusahaan manufaktur dalam negeri yang harus mengurangi jumlah karyawan masuk sehingga berdampak pada penurunan produksi. Kemudian dari penurunan jumlah produksi juga berdampak kepada penghasilan yang akan diperolehnya.

Pada kasus Indonesia merupakan kombinasi dua unsur yang terjadi secara bersamaan, dimana unsur eksternal berupa kepanikan keuangan dan lemahnya ekonomi nasional baik dari sektor perbankan maupun riil. Kedua faktor tersebut saling mempengaruhi dimana ketika gejolak eksternal timbul, maka perkekonomian nasional yang lemah sangat mudah terkena dampak negatif sehingga gejolak yang terjadi dalam waktu singkat akan berubah menjadi krisis ekonomi yang terjadi saat ini dan dirasakan oleh negara kita.

Pandemi Covid-19 berdampak negatif terhadap pertumbuhan ekonomi nasional di Indonesia pada triwulan II-2020. Akibatnya, perekonomian Indonesia pada triwulan II-2020

\footnotetext{
${ }^{19}$ Dini Selasi, "Dampak Pandemic Disease Terhadap Perkembangan Pasar Modal Syariah Di Indonesia," Jurnal Ilmiah Indonesia 5 (2020): 47.
} 
mengalami kontraksi sebesar 5,32\% setelah tumbuh 2,97\% pada triwulan I-2020.20 Berikut ini data pertumbuhan ekonomi dan jumlah pengangguran terbuka Indonesia 2010-2020:

Gambar 2.

Pertumbuhan Ekonomi dan pengangguran Terbuka Negara Indonesia Tahunan

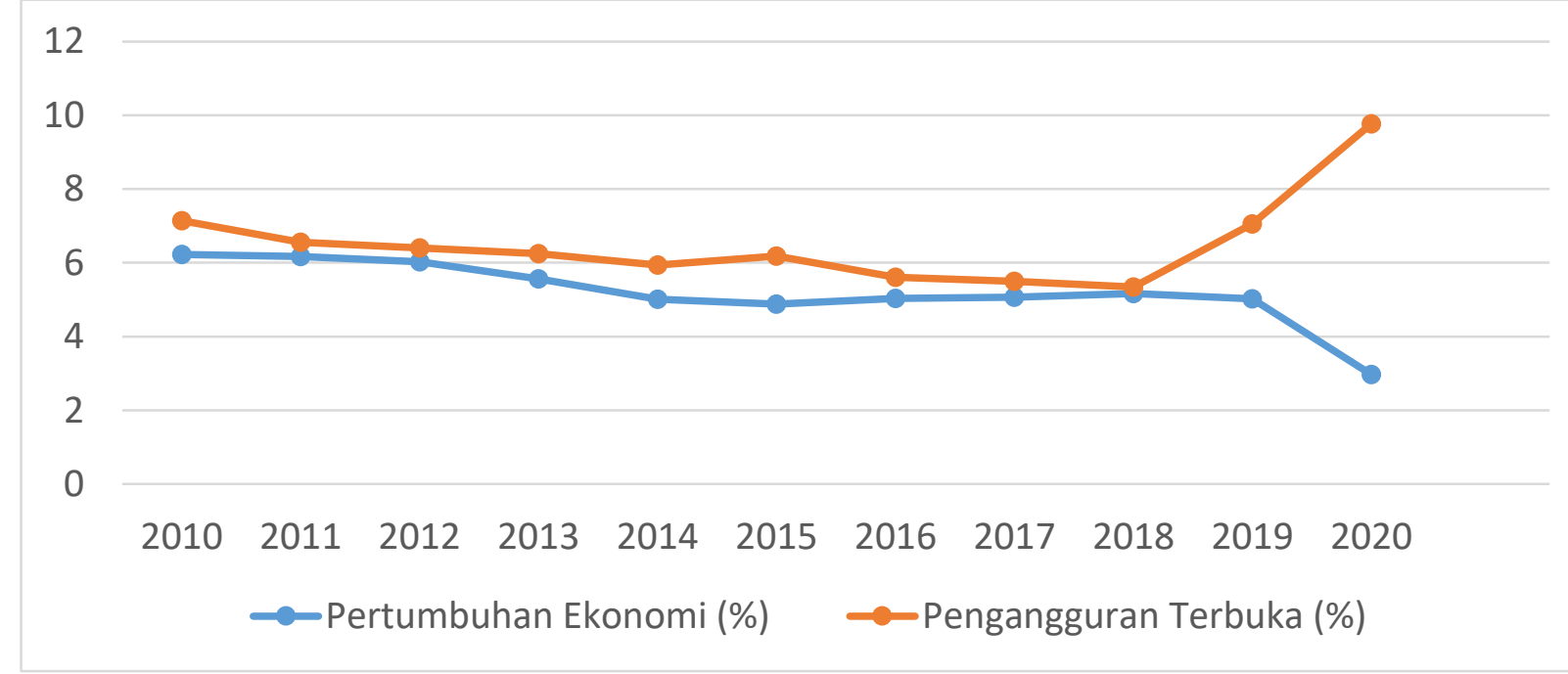

Sumber : Badan Pusat Statistik

Dari gambar tersebut dapat di pahami bahwa selama sepuluh tahun terakhir, pertumbuhan ekonomi Negara Indonesia cenderung menurun hingga di titik tahun 2020 hanya berada pada angka 2,97 persen. Sedangkan pada tingkat pengangguran terbuka sejak tahun 2018 sampai tahun 2020 mengalami kenaikan yang drastic diaman pada tahun 2020 pengangguran terbuka naik 2,72 poin persen hingga berada pada angka 9,77 persen dibandingkan tahun sebelumnya. Angka tersebut merupakan angka yang tidak baik terhadap keadaan ekonomi dan kesejahteraan Negara Indonesia.

Menteri Keuangan Sri Mulyani menyatakan bahwa konsumsi rumah tangga pada kuartal kedua tahun ini terjadinya penurunan yang sangat drastis menjadi $0 \%$. "Pemerintah sendiir memproyeksikan angka $-0,4 \%$ hingga 1,0\% untuk pertumbuhan ekonomi pada tahun 2020" ukar Sri Mulyani dalam rapat kerja DPR di Jakarta, Kamis (18 Juni 2020). Revisi pertumbuhan tersebut juga dikarenakan pertumbuhan ekonomi di kuartal kedua yang diyakini akan merosot tajam dibandingkan kuartal pertama yang tercatat 2,97\%. "Perekonomian 2,3\% kami revisi proyeksi turun ke 1\% karena kontraksi dalam kuartal II," jelas Sri Mulyani. Dalam skala makro, target kebijakan fiscal yang tertuang di dalam UndangUndang APBN nomor 20 Tahun 2019 tentang APBN 2020 tidak dapat dicapai dan dialihkan prioritasnya terutama ke sektor kesehatan seperti untuk pengadaan Alat Pengaman Diri (APD), alat test corona, pembangunan sarana kesehatan, dan pada fasilitas-fasilitas lainnya. Sektor lain yang juga diutamakan adalah jarring pengaman social dan penyelamatan sektor UMKM.

Kebijakan social distancing yang dipilih oleh pemerintah Indonesia telah membuat seluruh aktifitas produksi terganggu. Terdapat beberapa perusahaan yang mengambil kebijakan Work From Home, bebrapa lagi memutuskan untuk merumahkan karyawannya,

\footnotetext{
${ }^{20}$ Mohammad Orinaldi, "Relasi Antara Omnibus Law Di Era Pandemi Covid-19 Dan Perekonomian Di Indonesia," Jurnal Manajemen Dan Sains 5 (2020): 271.
} 
hingga terjadi PHK massal. Menurut data terbaru Dinas Tenaga Kerja, Transmigrasi dan Energi DKI Jakarta, sebanyak 30.137 pekerja dilaporkan harus kehilangan pekerjaan karena PHK massal, sedangkan 132.279 pekerja lainnya kehilangan penghasilan dikarenakan mereka dirumahkan tanpa upah. Efek dari hal tersebut tentunya telah membuat penurunan kapasitas produksi mengalami penurunan yang cukup ekstrim. Secara tidak langsung kondisi demikian telah menyebabkan bahan baku produksi industri rumah tangga mengalami kelangkaan atau bahkan mengalami kenaikan harga yang ekstrim. Sebagai contoh sektor UMKM pembuat makanan atau roti yang dipusingkan dengan melambungnya harga telur dan juga gula pasir. Hal ini tentu mengakibatkan harga jual produk tersebut juga harus dinaikkan. Pilihan ini tentunya tergolong sangat beresiko mengingat saat ini daya beli masyarakat sedang melemah.

Pemerintah terus berupaya untuk memaksimalkan jalur distribusi ke seluruh Indonesia lewat pembangunan infrastruktur besar-besaran di Indonesia. Hal tersebut bahkan sudah lama dimulai sejak Presiden Jokowi menjabat pada periode pertama. Hasilnyapun cukup singnifikan, jalur distribusi jadi lebih cepat, kesenjangan harga juga bisa dipangkas serta laju perekonomian rakyatpun semakin kencang. Namun saat ini, covid-19 telah menghancurkan semuanya. Berdasarkan data Asosiasi Tol Indonesia (ATI) lalu-lintas harian rata-rata seluruh jalan tol di Indonesia mengalami penurunan antara $40 \%$ sampai dengan $60 \%$ sejak awal Maret 2020. Dalam situasi ini pemerintah juga mengeluarkan kebijakan seperti pembatasan wilayah, pembatasan aktivitas dan social distancing. Kebijakan pemerintah ini dikeluarkan dengan tujuan untuk mengurangi dan mencegah terjadinya penyebaran covid-19 yang sangat memiliki dampak besar di berbagai sektor. Dalam hal ini, dampak tersebut juga mempengaruhi para pekerja informal yang mengalami penurunan pendapatan, dan juga penurunan pada konsumsi rumah tangga yang berdampak pada sektor keuangan seperti perbankan. tak hanya bank konvensional yang terkena dampaknya, akan tetapi pada perbankan syariahpun juga terkena dampak dari pandemi virus yang sangat berbahaya dan mematikan ini.

Akibat pandemi virus covid-19 ini, dampak yang dihadapi oleh bank-bank konvensional ataupun bank-bank syariah diantaranya adalah risiko pasar, risiko operasional, dan juga risiko kredit. Hal demikian tentunya mengakibatkan sektor perbankan mengeluarkan kebijakan terkait penundaan pembayaran kredit bagi nasabah yang telah disampaikan oleh Bapak Presiden Jokowi. Kebijakan tersebut disebabkan karena nasabah tidak mampu membayar hutang atau membayar kewajiban mereka kepada bank, dikarenakan dampak dari melemahnya perekonomian masyarkat yang berakibat pada menurunnya pendapatan masyarakat. Kebijakan ini merupakan salah satu upaya pemerintah dalam menjamin kehidupan masyarakat selama masa pandemi covid-19. Krisis pada sektor perbankan kian hari kian bertambah, hal tersebut mengakibatkan suplai dana tunai yang tersedia di perbankan juga akan menurun. Di lain sisi, bank juga tetap harus melunasi biaya operasional dan melunasi nisbah bagi hasil kepada pemilik dana pihak ketiga, sehingga hal demikian menyebabkan penurunan pendanaan pada bank koncensional maupun bank syariah. ${ }^{21}$

Salah satu dampak yang paling banyak menyentuh beberapa lapisan masyarakat dengan hadirnya Covid-19 ini yaitu Pemutusan Hubungan Kerja (PHK) yang dilakukan oleh beberapa perusahaan kepada para pekerja dengan alasan force majeure atau mengalami kerugian. Jika dahulunya UMKM dikelola dengan baik pengembangannya maka akan menjadi penolong untuk menyerap tenaga kerja untuk keadaan mendesak seperti masa pandemic

\footnotetext{
${ }^{21}$ Hanoatubun Silpa, "Dampak Covid-19 Terhadap Perekonomian Indonesia," Jurnal Pendidikan, Psikologi, Dan Konseling 2 (2020): 147.
} 
covid-19.22 Sebenarnya adanya pandemic covid-19 ini tidak selalu berdampak negative bagi semua orang. Terdapat sisi positif terhadap pelaku dunia usaha atau wirausaha yang mampu melirik peluang dan akan menguasai pasar dengan memaksimalkan perolehan keuntungan. Tetapi bagi bara wirausaha yang bergantung kepada interaksi pasar secara langsung harus menanggung konsekuensi penurunan omset selama masa pandemic covid-19 ini. Secara umum tingkat kerugian pelaku bisnis meningkat, namun demikian tentu di bagian lain akan memunculkan keutungan yang sangat berarti, terutama pihak-pihak yang mampu beradaptasi sangat cepat. ${ }^{23}$

Pemerintah dengan wewenangnya berusaha untuk membantu mengatasi masalahmasalah yang sedang di hadapi khususnya oleh Negara Indonesia. Berbagai kebijakan moneter dan fiscal kerap kali dikeluarkan untuk menstimulus keadaan ekonomi Negara. Implementasi kebijakan Fiskal di Indonesia yaitu berdasar PERPU No.1 Tahun 2020 mengenai Kebijakan dan Stabilitas Sektor Keuangan Negara yang berlaku sejak 31 Maret 2020, antara lain:

1. Penetapan batas deficit Anggaran Negara diatas 3\% dari PDB pada periode penanganan COVID-19 sampai tahun fiscal 2022 dan deficit akan kembali pada angka paling tinggi sebesar 3\% pada 2023.

2. Adanya penyesuaian tarif pajak, antara lain:

a. Pajak pendapatan perusahaan sebesar $22 \%$ pada 2020 dan 2021 , menjadi $20 \%$ di tahun 2022.

b. Pajak Penghasilan Badan Terbuka untuk Publik dengan kriteria jumlah saham yang disetor dapat diperjual belikan paling sedikit sebesar $40 \%$ dengan persyaratan tertentu, akan dengan tarif pajak 3\% lebih rendah dari pajak penghasilan pada poin 2a.

3. Kemudahan dalam pelaksanaan pajak yaitu:

a. Kebijakan pengajuan keringanan pajak akan diperpanjang hingga 6 bulan.

b. Masa pengembalian pajak hingga kurun waktu 1 tahun.

c. Waktu jatuh tempo tentang klaim pengembalian pajak, keberatan pajak, pengurangan atau penghapusan sanksi pajak diperpanjang dalam waktu 6 bulan.

4. Pembebasan kepabeanan dan cukai terhadap barang import yang terkait dengan pegembangan industri dalam Negeri.

Kemudian beberapa kebijakan moneter yang dikeluarkan oleh pemerintah yaitu diantaranya: Bank Indonesia sebagai lembaga yang menetapkan kebijakan moneter negara, tertuang dalam PERPU No 1 Tahun 2020 yaitu dengan memberikan wewenang kepada Bank Indonesia untuk memberi pinjaman likuiditas jangka pendek baik kepada bank baik sistemik maupun selain bank sistemik. Memberi akses penyaluran dana pada sektor swasta melalui repo utang Pemerintah melalui perbankan. Menerima pengajuan pinjaman likuiditas khusus jika bank sistemik yang sebelumnya telah menerima pinjaman likuiditas jangka pendek namun masih mengalami kesulitan likuiditas kepada BI. Selain kebijakan BI tersebut, Pemerintah juga akan mengatur program penjaminan selain program penjaminan simpanan dengan menerbitkan peraturan pemerintah untuk mencegah krisis system keuangan yang lebih dalam. OJK telah menerbitkan Peraturan OJK No. 11/PJOK. 03/2020, mengenai stimulus terhadap perekonomian nasional sebagai kebijakan counter cyclical dari dampak penyebaran Covid-19. Kebijakan ini berlaku untuk semua lembaga keuangan konvensional maupun syariah dan berlaku hingga 31 Maret 2021. Kebijakan OJK tersebut antara lain: mendukung diterapkannya kebijakan-kebijakan oleh Bank yang dapat memberikan rangsangan terhadap pertumbuhan ekonomi debitur dan UMKM yang terdampak oleh penyebaran COVID-19 serta

${ }^{22}$ Thamrin Tahir, Muhammad Hasan, and Ilham Thaief, Perubahan Paradigma Pendidikan Dan Ekonomi Di Masa Pandemi COVID-19 (Bandung: Media Sains Indonesia, 2020), 121.

${ }^{23}$ Herbert Siregar, Agus Rahayu, and Lili Adi Wibowo, "Manajemen Strategi Di Masa Pandemi Covid-19," KOMITMEN: Jurnal Ilmiah Manajemen 1 (2020): 56. 
yang mengalami kesulitan untuk memenuhi kewajiban pada Bank, kebijakan-kebijakan antara lain: menilai kualitas kredit meningkatkan kualitas pembiayaan dan mengatur tentang penilaian kualitas aset. Penyaluran Kredit lain yang baru oleh Bank kepada debitur dengan perlakuan khusus sesuai POJK. Serta melakukan pelaporan berkala oleh Bank sejak akhir April 2020.

\section{PENUTUP}

Selain dari sektor kesehatan, dampak yang sangat terasa dari pandemi covid-19 adalah pada sektor ekonomi. Pandemi virus covid-19 ini memberikan dampak yang cukup besar bagi perekonomian di Indonesia. Namun dampak tersebut bisa saja diminimalisir, hal itu tergantung dari kebijakan yang diambil oleh pemerintah untuk cara mengatasinya, karena hal ini menyebabkan banyaknya kegiatan ekonomi yang terganggu bahkan telah melumpuhkan semua badan ataupun lembaga perokonomian di Indonesia. Perbankan juga sangat merasakan dampak dari pandemic covid-19 ini, tidak hanya bank konvensional, akan tetapi bank syariah pun turut merasakan dampak dari adanya pandemi virus covid-19 ini. Langkah yang di ambil pemerintah guna meredam segala risiko yang ada yaitu dengan mengeluarkan beberapa kebijakan moneter dan fiscal yang diharapkan mampu memberikan stimulus terhadap keadan ekonomi Negara Indonesia. Tentunya banyak sekali ketidaksempurnaan dalam analisis ini. Hasilnya sangat mungkin sensitive terhadap asumsiasumsi yang digunakan. Kajian selanjutnya atau lebih formal tentunya sangat memerlukan sensitivity analysis terhadap asumsi dan parameterisasi yang akan dilakukan. Walaupun demikian, dalam artikel ini penulis telah mencoba untuk membuat asumsi sebaik mungkin disamping mengandalkan referensi-referensi yang sangat kredibel. Tentu saja kritik dan saran yang sifatnya membangun dan menyempurnakan dari analisis ini sangat diharapkan dan akan disambut dengan apresiasi yang cukup besar.

\section{DAFTAR PUSTAKA}

Arifudin, Opan, Udin Wahrudin, and Fenny Damayanti Rusmana. Manajemen Risiko. Bandung: Widina Bhakti Persada, 2020.

$\mathrm{H}$, Iswahyudi. "Back to Oil: Indonesia Economic Growth After Asian Financial Crisis." Economic Journal of Emerging Markets 8 (2016).

Handayani, Diah. “Penyakit Virus Corona 2019." Jurnal Respirologi Indonesia 40 (2020).

Hery. Manajemen Risiko Bisnis. Jakarta: PT. Grasindo, 2015.

Ikawaty, Risma. "Corona Virus," 2020. https://www.ubaya.ac.id/2020/ content/articles_ detail/288/ CORONAVIRUS-.

"JHU CSSE COVID-19 Data," n.d.

L, Yang, and Ren Y. "Moral Obligation, Public Leadership, and Collective Action for Epidemic Prevention and Control: Evidence from the Corona Virus Disease 2019 (COVID-19) Emergency." International Journal of Environmental Research and Public Health 17 (2020).

Maralis, Reni, and Aris Triyono. Manajemen Risiko. Yogyakarta: CV. Budi Utama, 2019.

Muhlis. "Strategi Manajemen Risiko Pemanfaatan Teknologi Pada Lembaga Keuangan Syariah Era Millennial Dan Covid 19." Ar-Ribh: Jurnal Ekonomi Islam 3 (2020).

Orinaldi, Mohammad. "Relasi Antara Omnibus Law Di Era Pandemi Covid-19 Dan Perekonomian Di Indonesia." Jurnal Manajemen Dan Sains 5 (2020).

P, Sugarda, and Rifky W. "Strengthening Indonesia's Economic Resilience through Regulatory Reforms in Banking, Investment and Competition Law." Journal of Economic \& Management Perspectives 11 (2017).

Sari, Milya, and Asmendri. "Penelitian Kepustakaan (Library Research) Dalam Penelitian Pendidikan IPA." NATURAL SCIENCE: Jurnal Penelitian Bidang IPA Dan Pendidikan IPA $6(2020)$. 
Selasi, Dini. "Dampak Pandemic Disease Terhadap Perkembangan Pasar Modal Syariah Di Indonesia." Jurnal Ilmiah Indonesia 5 (2020).

Siahaan, Hinsa. Manajemen Risiko Konsep, Kasus Dan Implementasi. Jakarta: PT. Elek Media Komputindo, 2007.

Silpa, Hanoatubun. "Dampak Covid-19 Terhadap Perekonomian Indonesia." Jurnal Pendidikan, Psikologi, Dan Konseling 2 (2020).

Siregar, Herbert, Agus Rahayu, and Lili Adi Wibowo. "Manajemen Strategi Di Masa Pandemi Covid-19." KOMITMEN: Jurnal Ilmiah Manajemen 1 (2020).

Siswanti, Indra, Conie Nopinda, Novita Butarbutar, and Edwin Basmar. Manajemen Risiko Perusahaan. Medan: Yayasan Kita Menulis, 2020.

Susetyo, Aris, and Anton Prasetyo. "Pelatihan Manajemen Resiko Bagi Usaha Mikro Kecil Dan Menengah Di Era Pandemi Covid-19." Journal of Community Service and Empowerment 1 (2020).

Tahir, Thamrin, Muhammad Hasan, and Ilham Thaief. Perubahan Paradigma Pendidikan Dan Ekonomi Di Masa Pandemi COVID-19. Bandung: Media Sains Indonesia, 2020. 